\title{
Perbedaan Peningkatan Kemampuan Komunikasi Matematis dan Self-Confidence antara Siswa yang Mendapatkan DL dan PBL
}

\author{
Ranti Santika Dewi ${ }^{1}$, Rostina Sundayana ${ }^{2}$, dan Reni Nuraeni ${ }^{*}$ \\ 1,2,3*Program Studi Pendidikan Matematika, Fakultas Ilmu Terapan dan Sains, IPI Garut \\ Jln. Pahlawan No 32, Sukagalih, Tarogong Kidul, Garut, Jawa Barat, Indonesia \\ ${ }^{1}$ rantisantika26@gmail.com; ${ }^{2}$ sundayanaros@gmail.com; ${ }^{3 *}$ reni.n2409@gmail.com
}

Artikel diterima: 14-08-2020, direvisi: 29-09-2020, diterbitkan: 30-09-2020

\begin{abstract}
Abstrak
Rendahnya kemampuan komunikasi matematis dan Self Confidence siswa berpengaruh terhadap prestasi dalam pembelajaran matematika. Perlu upaya untuk meningkatkan kemampuan komunikasi dan Self Confidence siswa salah satunya dengan menggunakan model Discovery Learning dan Problem Based Learning. Tujuan penelitian untuk menganalisis perbedaan peningkatan kemampuan komunikasi matematis dan Self Confidence antara siswa yang mendapatkan model Discovery Learning dan Problem Based Learning. Metode penelitian yang digunakan adalah kuasi eksperimen dengan populasi seluruh siswa kelas X SMA Negeri 2 Garut. Sampel pada penelitian ini sebanyak dua kelas yaitu X MIPA 1 sebagai kelas eksperimen 1 sebanyak 35 siswa yang mendapat model Discovery Learning dan X MIPA 2 sebagai kelas eksperimen 2 sebanyak 33 siswa yang mendapat model Problem Based Learning. Instrumen penelitian yang digunakan berupa tes uraian dan angket skala Bandura. Berdasarkan hasil analisis secara statistik diperoleh kesimpulan bahwa terdapat perbedaan peningkatan kemampuan komunikasi matematis antara siswa yang mendapatkan model Discovery Learning dan Problem Based Learning serta terdapat perbedaan peningkatan Self Confidence antara siswa yang mendapatkan model Discovery Learning dan Problem Based Learning.

Kata Kunci: Komunikasi Matematis, Discovery Learning, Problem Based Learning, Self Confidence.

\section{Differences in The Improvement of Mathematical Communication Skill and Self Confidence between Studens Who Get the Discovery Learning and Problem Based Learning}

\begin{abstract}
The low mathematical communication skills and Self Confidence of the students affect achievement in mathematics learning. It is worth the effort to improve communication skills and Self Confidence of the students one by using the model of Discovery Learning and Problem Based Learning. Research purposes to analyze the differences in the increase in mathematical communication skills and Self Confidence among the students who get the model of Discovery Learning and Problem Based Learning. The research method used is a quasi-experiment with the entire population of students of class X SMA Negeri 2 Garut. The sample in this study were two classes, namely X MIPA 1 as a class experiment 1 as many as 35 students who received Discovery model Learning and X MIPA 2 as a class experiment 2 a total of 33 students who received the model of Problem Based Learning. The research instrument used in the form of test descriptions and questionnaire scale Bandura. Based on the results of the analysis of statistically obtained the conclusion that there are differences in mathematical communication skills among the students who get the model of Discovery Learning and Problem Based Learning as well as there are differences in the increase in Self Confidence among the students who get the model of Discovery Learning and Problem Based Learning.

Keywords: Mathematical Communication Skills, Model Discovery Learning, Problem Based Learning model, Self Confidence.
\end{abstract}




\section{Pendahuluan}

Seiring dengan perkembangan sains dan teknologi, siswa harus mampu mengikutinya, salah satunya dengan menguasai matematika. Matematika sebagai penunjang ilmu lain dan menjadi salah satu ilmu yang mendasari kehidupan manusia (Afriansyah, 2013). Sangatlah penting mempelajari matematika. Sesuai dengan pendapat Hudoyo (2003, hlm. 35) yaitu untuk menghadapi kehidupan seharihari dan perkembangan iptek diperlukan cara berpikir yang didasari dan dikembangkan oleh matematika.

Saat ini teknologi informasi dan komunikasi lebih diutamakan di era revolusi industri 4.0. Untuk menyesuaikan revolusi industri 4.0 dan tujuan pembelajaran matematika itu sendiri, siswa harus menguasai kemampuan matematis salah satunya yaitu kemampuan komunikasi. Izzati (2010, hlm. 721) mengemukakan bahwa kemampuan mengekspresikan gagasan dengan tepat, singkat dan logis, serta argumen yang tepat, singkat, dan logis dengan menggunakan bahasa matematika merupakan kemampuan komunikasi dalam matematika. Bila kemampuan komunikasi matematis siswa baik, hal ini dapat menstimulus kemampuan siswa dalam mengembangkan ide gagasan dan pengetahuannya dalam menemukan konsep matematika yang sedang dipelajari.
Selain kemampuan kognitif yaitu kemampuan komunikasi matematis, kemampuan afektif juga dipandang sangat perlu dikembangkan, salah satunya yaitu self-confidence atau biasa juga disebut kepercayaan diri siswa. Hannula, Hanna dan Erkki (2004) mengemukakan bahwa kunci sukses belajar matematika itu adalah percaya akan kemampuan yang dimilik oleh diri sendiri serta percaya pada matematika itu sendiri. Bila siswa memiliki rasa percaya diri tinggi akan membuat prestasinya meningkat, karena siswa akan percaya pada kemampuan diri untuk menyelesaikan masalah yang dihadapinya.

Kemampuan komunikasi matematis dan self confidence haruslah dimiliki oleh siswa, karena mengingat betapa pentingnya kemampuan tersebut. Mengingat masih rendahnya kemampuan siswa tersebut di Indonesia, diperlukan suatu upaya untuk mengatasinya (Sofyan \& Madio, 2017; Asmara \& Afriansyah, 2018). Menurut Nizam (dalam Hadi \& Novaliyosi, 2019) hasil terbaru dari TIMSS 2015 menunjukkan nilai rata-rata Indonesia yakni sebesar 397 berada di peringkat 44 dari 49 negara. Begitupun dengan kemampuan self Confidence, menurut Agustyaningrum \& Widjajanti (dalam Niviayana, Rachmani dan Rochmad, 2019) bahwa dari hasil analisis angket dalam penelitian didapat 18 siswa $(26,47 \%)$ memiliki tingkat kepercayaan diri yang kurang dari 70\%, sedangkan 
kepercayaan diri terhadap pembelajaran matematika hanya sebesar $74,03 \%$.

Proses pembelajaran merupakan salah satu faktor penyebab rendahnya kedua kemampuan tersebut, dikarenakan sistem pembelajaran yang tidak melibatkan siswa untuk ikut serta aktif, dan mengabaikan keaktifan siswa karena dianggap bukan sebagai pusat pembelajaran. Seperti halnya yang diungkapkan oleh Soedijarto (dalam Dewi, 2013, hlm. 6) bahwa dalam proses kegiatan pembelajaran tidak menggunakan pendekatan yang modern, hanya merupakan serangkaian kegiatan mencatat, kemudian dihafal serta mengingat kembali, itu merupakan ciri dari proses pembelajaran yang dilakukan di kebanyakan negara berkembang, salah satunya negara Indonesia. Hal ini membuat siswa tidak kreatif karena hanya menerima informasi dari guru tanpa adanya proses mengekspresikan ide-ide yang dimilikinya dalam menemukan suatu konsep matematika.

Pembelajaran yang dapat diterapkan untuk peningkatan kemampuan komunikasi matematis dan Self Confidence siswa adalah melalui pembelajaran aktif, yaitu Discovery Learning dan Problem Based Learning. Suherman dkk. (2003, hlm. 190) menyatakan bahwa model Discovery Learning merupakan kegiatan pembelajaran yang menekankan pada penemuan karena siswa berperan aktif dalam pembelajaran dan guru hanya sebagai pembimbing saja, sehingga proses kegiatan ini akan memfasilitasi peningkatan motivasi siswa dalam belajar matematika. Problem Based Learning merupakan salah satu pembelajaran yang dapat memfasilitasi dan mengembangkan kemampuan komunikasi matematis siswa (Duch, dkk, 2001; Savin-Baden \& Major, 2004; Ali, et al, 2010; Damayanti \& Afriansyah, 2018). Kesimpulan yang didapat bahwa untuk memfasilitasi peningkatan kemampuan komunikasi matematis serta self confidence siswa diperlukan suatu pembelajaran yang membuat siswa aktif dalam pembelajaran, tidak hanya menerima materi dari guru, serta siswa mampu menggali pengetahuan siswa itu sendiri.

Rumusan masalah dalam penelitian adalah: (1) Bagaimana kualitas peningkatan kemampuan komunikasi matematis yang mendapatkan model Discovery Learning?; (2) Bagaimana kualitas peningkatan kemampuan komunikasi matematis yang mendapatkan model Problem Based Learning?; (3) Apakah terdapat perbedaan peningkatan kemampuan komunikasi matematis antara siswa yang mendaptkan model Discovery Learning dan Problem Based Learning?; (4) Bagaimana kualitas peningkatan Self Confidence siswa yang mendapatkan model Discovery Learning?; (5) Bagaimana kualitas peningkatan Self Confidence siswa yang mendapatkan model Problem Based Learning?; (6) Apakah terdapat perbedaan peningkatan Self Confidence antara siswa yang mendaptkan model Discovery Learning dan Problem Based Learning?. 
Adapun tujuan dalam penelitian ini adalah: (1) Menganalisis kualitas peningkatan kemampuan komunikasi matematis siswa yang mendapatkan model Discovery Learning; Menganalisis kualitas peningkatan kemampuan komunikasi matematis siswa yang mendapatkan model Problem Based Learning; (3) Mengkaji perbedaan peningkatan kemampuan komunikasi matematis siswa yang mendapat model Discovery Learning dan Problem Based Learning; (4) Menganalisis kualitas peningkatan Self Confidence siswa yang mendapatkan model Discovery Learning. (5) Menganalisis kualitas peningkatan Self Confidence siswa yang mendapatkan model Problem Based Learning; (6) Mengkaji perbedaan peningkatan Self Confidence siswa yang mendapat model Discovery Learning dan Problem Based Learning.

Dalam penelitian ini, yang dikaji adalah kemampuan komunikasi siswa berupa kemampuan tertulis. Untuk mengukur kemampuan komunikasi matematis, peneliti mengambil indikator yang dikemukakan oleh Sumarmo (dalam Hendriana, Rochaeti \& Sumarmo, 2017, hlm.62) sebagai berikut: (1) Menyatakan benda-benda nyata, situasi dan peristiwa sehari-hari ke dalam bentuk model matematik (gambar, tabel, diagram, grafik, ekspresi aljabar); (2) Menjelaskan ide dan model matematika (gambar, tabel, diagram, grafik, ekspresi aljabar); (3)
Menjelaskan dan membuat pertanyaan matematika yang dipelajari; (4) Membuat konjektur, menyusun argumen, merumuskan definisi dan generalisasi.

Sedangkan indikator Self Confidence yang dikaji pada penelitian ini adalah indikator yang dikemukakan oleh Lautser (dalam Nur Ghufron \& Rini, 2011, hlm. 355-36) sebagai berikut: (1) Keyakinan kemampuan diri yaitu sikap positif seseorang tentang dirinya atas kemampuan yang dimilikinya. Sehingga dia mampu secara sungguh-sungguh akan apa yang dilakukannya; (2) Optimis yaitu sikap positif yang dimiliki seseorang yang selalu berpandangan baik dalam menghadapi segala hal tentang diri dan kemampuannya; (3) Objektif yaitu seseorang yang memandang permasalahan sesuai dengan kebenaran yang semestinya, bukan menurut dirinya; (4) Bertanggung jawab yaitu kesediaan seseorang untuk menanggung segala sesuatu yang telah menjadi konsekuensinya; (5) Rasional dan realistis yaitu menganalisis suatu masalah, sesuatu hal dan suatu kejadian oleh akal dan sesuai dengan kenyataan.

Dalam tahap pelaksanaan model Discovery Learning menurut Kurniasih dan Berlin (2014, hlm. 68-71) terdapat enam langkah yaitu: (1) Stimulation (stimulasi/ pemberian rangsangan), pada tahap ini guru memberikan suatu permasalahan yang menantang siswa dalam memecahkan suatu permasalahan, 
sehingga timbul keinginan siswa untuk menyelesaikannya. Pada tahap ini juga guru bisa mengawali pembelajaran dengan memberikan pertanyaan, anjuran membaca buku sumber untuk memfasilitasi siswa dalam menyelesaikan masalah; (2) Problem Statment (pernyataan/ identifikasi masalah), guru memberikan kesempatan kepada siswa untuk mengindetifikasi sebanyak mungkin masalah yang relevan dengan bahan pelajaran. Kemudian salah satunya dipilih dan dirumuskan dalam bentuk hipotesis. (3) Data Collection (pengumpulan data), pada tahap ini siswa diberikan kesempatan untuk membuktikan hipotesis yang dibuat, dengan cara mengamati objek, membaca sumber literatur, mencari dan mengumpulkan berbagai informasi yang relevan dengan masalah yang sedang dikaji, melakukan uji coba dengan kemampuan sendiri, dan lain sebagainya; (4) Data Processing (pengolahan data), Data yang telah dikumpulkan kemudian diolah, dihitung untuk memperoleh jawaban apakah sesuai dengan hipotesis atau tidak; (5) Verification (pembuktian), siswa melakukan pemeriksanaan secara cermat dan teliti untuk membuktikan kebenaran hipotesis yang ditetapkan sebelumnya, serta dihubungkan dengan hasil pengolahan data; (6) Generalization (menarik kesimpulan), penyimpulan yang dapat dijadikan prinsip umum berlaku untuk semua masalah yang sama dengan memperhatikan hasil verifikasi.
Sedangkan Arends

(2009) mengemukakan sintaks Problem Based Learning seperti pada Tabel 1.

Tabel 1. Sintaks Model PBL

\begin{tabular}{|c|c|}
\hline Tahap & Kegiatan Pendidik \\
\hline $\begin{array}{l}\text { Tahap 1: } \\
\text { Melakukan masalah } \\
\text { pada peserta didik }\end{array}$ & $\begin{array}{l}\text { Pendidik menjelaskan tujuan } \\
\text { pembelajaran, menjelaskan } \\
\text { logistik (bahan dan alat) apa } \\
\text { yang dibutuhkan bagi } \\
\text { penyelesaian masalah serta } \\
\text { memotivasi peserta didik untuk } \\
\text { terlibat dalam pemecahan } \\
\text { masalah yang dipilih. }\end{array}$ \\
\hline $\begin{array}{l}\text { Tahap 2: } \\
\text { Mengorganisasikan } \\
\text { peserta didik untuk } \\
\text { belajar }\end{array}$ & $\begin{array}{l}\text { Pendidik membantu peserta } \\
\text { didik untuk mendefinisikan } \\
\text { tugas belajar yang } \\
\text { berhubungan dengan masalah } \\
\text { tersebut. }\end{array}$ \\
\hline $\begin{array}{l}\text { Tahap 3: } \\
\text { Membimbing } \\
\text { kelompok investigasi }\end{array}$ & $\begin{array}{l}\text { Pendidikan mendorong peserta } \\
\text { didik untuk mengumpulkan } \\
\text { informasi yang sesuai, } \\
\text { melaksanakan eksperimen } \\
\text { untuk mendapatkan penjelasan } \\
\text { dan pemecahan masalah. }\end{array}$ \\
\hline $\begin{array}{l}\text { Tahap 4: } \\
\text { Mengembangkan } \\
\text { dan menyajikan } \\
\text { hasil karya }\end{array}$ & $\begin{array}{l}\text { Pendidik membantu peserta } \\
\text { didik dalam merencanakan dan } \\
\text { menyiapkan karya yang sesuai } \\
\text { dengan tugas yang diberikan } \\
\text { seperti laporan, video dan } \\
\text { model serta membantu mereka } \\
\text { untuk berbagai tugas } \\
\text { temannya. }\end{array}$ \\
\hline $\begin{array}{l}\text { Tahap 5: } \\
\text { Menganalisis dan } \\
\text { mengevaluasi } \\
\text { proses pemecahan } \\
\text { masalah }\end{array}$ & $\begin{array}{l}\text { Pendidik membantu peserta } \\
\text { didik untuk melakukan refleksi } \\
\text { atau evaluasi terhadap hasil } \\
\text { penyelidikannya, proses-proses } \\
\text { pembelajaran yang telah } \\
\text { dilaksanakan. }\end{array}$ \\
\hline
\end{tabular}

Berdasarkan hasil penelitian Andini, Mulyani, Wijaya dan Supriyati (2018) menyimpulkan bahwa pencapaian kemampuan komunikasi matematis dan Self Confidence siswa yang pembelajaranya menggunakan Problem 
Based Learning berbantuan Geogebra lebih baik daripada pembelajaran biasa. Begitu pula berdasarkan hasil penelitian Sari (2016) menyimpulkan bahwa model Discovery Learning berpengaruh terhadap peningkatan Self Confidence siswa. Penelitian ini mengkaji mengenai peningkatan kemampuan komunikasi matematis dan self-confidence siswa yang diberikan pembelajaran Discovery Learning dan Problem Based Learning.

\section{Metode}

Metode yang digunakan pada penelitian ini adalah metode kuasi eksperimen dengan sampel sebanyak dua kelompok. Kelompok eksperimen 1 adalah kelompok yang diberikan perlakuan Discovery Learning dan kelompok eksperimen 2 adalah kelompok yang diberikan Problem Based Learning. Kegiatan pertama pada penelitian ini adalah dengan memberikan pretest dan pengisian angket Self Confidence awal dengan tujuan untuk mengetahui kemampuan awal dan tingkat kepercayaan diri awal siswa baik pada kelas eksperimen 1 maupun kelas eksperimen 2. Setelah proses pembelajaran selesai, peneliti memberikan posttest dan angket Self Confidence akhir untuk membedakan hasil belajar dari kedua kelas tersebut.

Desain penelitian ini dinamakan Nonequivalen Control Group, yang dikemukakan oleh Ruseffendi (2005, hlm. 53) sebagai berikut:

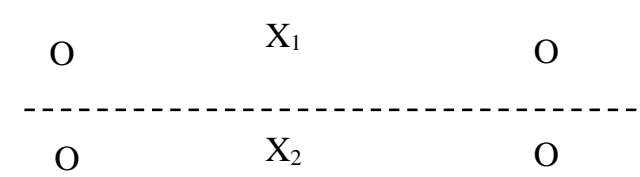

Keterangan:

$\mathrm{O}=$ Tes pretest dan posttest

$\mathrm{X}_{1}=$ Pembelajaran menggunakan model Discovery Learning

$\mathrm{X}_{2}=$ Pembelajaran menggunakan model Problem Based Leaning

.... = Kedua kelompok tidak dipilih secara random

Populasi dalam penelitian ini adalah siswa kelas X SMA Negeri 2 Garut tahun ajaran 2019-2020. Sampel dalam penelitian ini diambil dua kelas yang dipilih secara purposive sampling yaitu pengambilan kelompok yang didasarkan kepada pertimbangan tertentu (Sugiono, 2011). Sampel yang diambil sebagai kelas Discovery Learning yaitu X MIPA 1 dan kelas Problem Based Learning yaitu X MIPA 2.

Sebelum dilakukannya masing-masing model pembelajaran, kedua sampel diberikan pretest dan angket awal untuk mengetahui kemampuan awal siswa. Kemudian diberikan perlakuan setiap model. Setelah itu kedua sampel diberikan posstest dan angket akhir untuk mengetahui kemampuan siswa setelah mendapatkan masing-masing model pembelajaran. Instrumen yang diberikan yaitu berupa tes mengenai materi Sistem Pertidaksamaan Dua Variabel (Linear- 
Kuadrat dan Kuadrat-Kuadrat), dan angket mengenai self confidence.

Analisis data dilakukan untuk mengetahui hasil dari penelitian setelah diberikan perlakuan model pembelajaran. Data yang dianalisis diperoleh dari hasil Pretest, Posttest, penyebaran angket awal dan akhir, Gain Ternormalisasi.

\section{Hasil dan Pembahasan}

Dari data hasil penelitian dengan perlakuan kepada dua kelas yang berbeda yaitu kelas yang mendapatkan model Discovery Learning yang berjumlah 35 siswa dan kelas yang mendapatkan model Problem Based Learning yang berjumlah 33 siswa. Kedua kelas tersebut diberikan pretest, posttest, angket awal dan akhir dengan hasil sebagai berikut.

Tabel 2.

Data Hasil Penelitian Kemampuan Komunikasi Matematis Siswa

\begin{tabular}{|c|c|c|c|c|c|c|}
\hline & mpok & \multirow{2}{*}{$\begin{array}{c}\begin{array}{c}\text { Jum- } \\
\text { lah } \\
\text { Siswa }\end{array} \\
35\end{array}$} & \multirow{2}{*}{$\begin{array}{c}\text { Skor } \\
\text { Maks. } \\
4\end{array}$} & \multirow{2}{*}{$\begin{array}{l}\text { Skor } \\
\text { Min. } \\
0\end{array}$} & \multirow{2}{*}{$\begin{array}{c}\begin{array}{c}\text { Rata- } \\
\text { Rata }\end{array} \\
0,97\end{array}$} & \multirow{2}{*}{$\begin{array}{c}\begin{array}{c}\text { Simpa- } \\
\text { ngan } \\
\text { Baku }\end{array} \\
1,10\end{array}$} \\
\hline $\begin{array}{l}D \\
L\end{array}$ & $\begin{array}{l}\text { Pre- } \\
\text { test }\end{array}$ & & & & & \\
\hline & $\begin{array}{c}\text { Post- } \\
\text { test }\end{array}$ & 35 & 15 & 7 & 8,97 & 2,15 \\
\hline & Gain & 35 & 0,94 & 0,33 & 0,53 & 0,14 \\
\hline $\begin{array}{l}P \\
B\end{array}$ & $\begin{array}{l}\text { Pre- } \\
\text { test }\end{array}$ & 33 & 5 & 0 & 1,39 & 1,46 \\
\hline $\mathrm{L}$ & $\begin{array}{c}\text { Post- } \\
\text { test }\end{array}$ & 33 & 16 & 6 & 11,45 & 2,96 \\
\hline & Gain & 33 & 1,00 & 0,33 & 0,69 & 0,20 \\
\hline
\end{tabular}

Dari Tabel 2 diperoleh bahwa nilai ratarata posttest maupun gain pada kelas Problem Based Learning lebih besar dibandingkan dengan kelas Discovery Learning, terlihat bahwa terdapat perbedaan peningkatan kemampuan komunikasi matematis dari kedua kelas.
Tabel 3.

Data Hasil Self Confidence Siswa

\begin{tabular}{|c|c|c|c|c|c|c|}
\hline \multicolumn{2}{|c|}{ Kelompok } & \multirow{2}{*}{$\begin{array}{c}\begin{array}{c}\text { Jumlah } \\
\text { Siswa }\end{array} \\
35\end{array}$} & \multirow{2}{*}{$\begin{array}{c}\begin{array}{c}\text { Skor } \\
\text { Maks. }\end{array} \\
54,43\end{array}$} & \multirow{2}{*}{$\begin{array}{l}\begin{array}{l}\text { Skor } \\
\text { Min. }\end{array} \\
31,86\end{array}$} & \multirow{2}{*}{$\begin{array}{c}\begin{array}{c}\text { Rata- } \\
\text { Rata }\end{array} \\
43,16\end{array}$} & \multirow{2}{*}{$\begin{array}{c}\begin{array}{c}\text { Simpangan } \\
\text { Baku }\end{array} \\
4,90\end{array}$} \\
\hline DL & $\begin{array}{c}\text { Angket } \\
\text { Awal }\end{array}$ & & & & & \\
\hline & $\begin{array}{l}\text { Angket } \\
\text { Akhir }\end{array}$ & 35 & 70,76 & 42,63 & 55,47 & 7,21 \\
\hline & Gain & 35 & 1,00 & 0,10 & 0,45 & 0,23 \\
\hline \multirow[t]{3}{*}{ PBL } & $\begin{array}{c}\text { Angket } \\
\text { Awal }\end{array}$ & 33 & 50,48 & 30,51 & 41,65 & 4,75 \\
\hline & $\begin{array}{c}\text { Angket } \\
\text { Akhir }\end{array}$ & 33 & 66,64 & 47,90 & 57,57 & 5,03 \\
\hline & Gain & 33 & 1,00 & 0,30 & 0,64 & 0,19 \\
\hline
\end{tabular}

Dari Tabel 3 diperoleh bahwa nilai ratarata angket akhir maupun gain pada kelas Problem Based Learning lebih besar dibandingkan dengan kelas Discovery Learning, terlihat bahwa terdapat perbedaan peningkatan Self Confidence siswa dari kedua kelas.

Adapun rincian kualitas peningkatan kemampuan komunikasi matematis dan Self Confidence siswa yang mendapatkan model Discovery Learning dan model Problem Based Learning sebagai berikut.

Tabel 4.

Data Hasil Gain Ternormalisasi Kelas Model Discovery Learning

\begin{tabular}{|c|c|c|c|c|c|c|c|}
\hline $\begin{array}{l}\mathrm{Jlm} \\
\text { Sis- } \\
\text { wa }\end{array}$ & $\begin{array}{l}\text { Nilai } \\
\text { Maks }\end{array}$ & $\begin{array}{l}\text { Nilai } \\
\text { Min }\end{array}$ & $\begin{array}{l}\text { Rata- } \\
\text { rata }\end{array}$ & $\begin{array}{l}\text { Simp } \\
\text { Baku }\end{array}$ & $\begin{array}{l}\text { Inter- } \\
\text { Pretasi }\end{array}$ & $\mathrm{Fi}$ & $\begin{array}{l}\text { Pre- } \\
\text { senta } \\
\text { se (\%) }\end{array}$ \\
\hline \multirow[t]{2}{*}{35} & 0,94 & 0,33 & 0,53 & 0,14 & Sedang & 30 & 86 \\
\hline & & & & & Tinggi & 5 & 14 \\
\hline \multicolumn{6}{|c|}{ Jumlah } & 35 & 100 \\
\hline
\end{tabular}

Dari data presentase di atas ditunjukkan bahwa kualitas peningkatan kemampuan komunikasi matematis siswa yang mendapatkan model Discovery Learning sebagian besar berinterpretasi sedang.

Tabel 5. 
Data Hasil Gain Ternormalisasi Kelas Model Problem Based Learning

\begin{tabular}{|c|c|c|c|c|c|c|c|}
\hline $\begin{array}{c}\text { Jlm } \\
\text { Sisw } \\
\text { a }\end{array}$ & $\begin{array}{l}\text { Nilai } \\
\text { Maks }\end{array}$ & $\begin{array}{l}\text { Nilai } \\
\text { Min }\end{array}$ & $\begin{array}{l}\text { Rata- } \\
\text { rata }\end{array}$ & $\begin{array}{l}\text { Simp. } \\
\text { Baku }\end{array}$ & $\begin{array}{l}\text { Inter- } \\
\text { Pretasi }\end{array}$ & $\mathrm{Fi}$ & $\begin{array}{c}\text { Prese } \\
\text { ntase } \\
\text { (\%) }\end{array}$ \\
\hline \multirow[t]{2}{*}{33} & 1,00 & 0,33 & 0,69 & 0,20 & Sedang & 14 & 42 \\
\hline & & & & & Tinggi & 19 & 58 \\
\hline \multicolumn{6}{|c|}{ Jumlah } & 33 & 100 \\
\hline
\end{tabular}

Dari data presentase di atas ditunjukkan bahwa kualitas peningkatan kemampuan komunikasi matematis siswa yang diberi perlakuan model Problem Based Learning sebagian besar berinterpretasi tinggi.

Tabel 6.

Data Angket Hasil Gain Ternormalisasi Kelas Model Discovery Learning

\begin{tabular}{|c|c|c|c|c|c|c|c|}
\hline $\begin{array}{c}\text { Jlm } \\
\text { Sisw } \\
\text { a }\end{array}$ & $\begin{array}{l}\text { Nilai } \\
\text { Maks }\end{array}$ & $\begin{array}{l}\text { Nilai } \\
\text { Min }\end{array}$ & $\begin{array}{l}\text { Rata- } \\
\text { rata }\end{array}$ & $\begin{array}{l}\text { Simp. } \\
\text { Baku }\end{array}$ & $\begin{array}{c}\text { Inter } \\
- \\
\text { Preta } \\
\text { si }\end{array}$ & $\mathrm{Fi}$ & $\begin{array}{l}\text { Pre- } \\
\text { sen- } \\
\text { tase } \\
\text { (\%) }\end{array}$ \\
\hline \multirow[t]{4}{*}{35} & 1,00 & 0,10 & 0,45 & 0,23 & $\begin{array}{c}\text { Rend } \\
\text { ah }\end{array}$ & 11 & 31 \\
\hline & & & & & $\begin{array}{c}\text { Seda } \\
\text { ng }\end{array}$ & 17 & 49 \\
\hline & & & & & $\begin{array}{c}\text { Tingg } \\
i\end{array}$ & 7 & 20 \\
\hline & \multicolumn{5}{|c|}{ Jumlah } & 35 & 100 \\
\hline
\end{tabular}

Dari data presentase di atas ditunjukkan bahwa kualitas peningkatan Self Confidence siswa yang mendapatkan model Discovery Learning sebagian besar berinterpretasi sedang.

Tabel 7.

Data Angket Hasil Gain Ternormalisasi Kelas Model Problem Based Learning

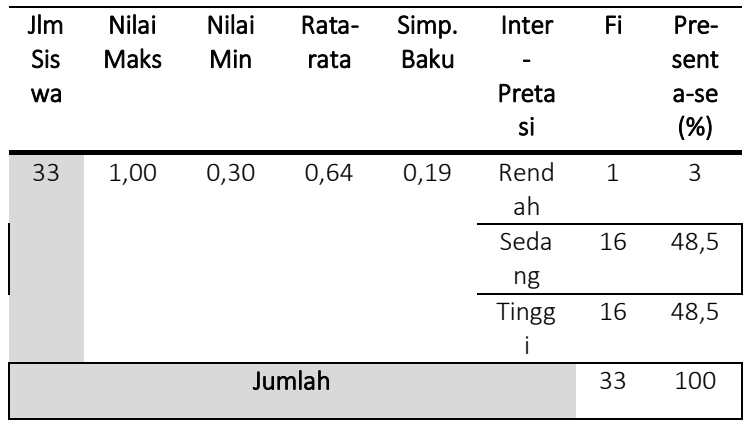

Dari data presentase di atas ditunjukkan bahwa kualitas peningkatan Self Confidence siswa yang mendapatkan model Problem Based Learning dengan interpretasi sedang dan tinggi memperoleh hasil yang sama.

Sebelum model pembelajaran diberikan terhadap kedua kelas, terlebih dahulu kedua kelas itu diberikan tes awal atau pretest untuk mengetahui kemampuan awal yang dimiliki, dengan rata-rata pada masing-masing kelas yaitu 0,97 dan 1,39. Setelah selesai pembelajaran, siswa diberikan posttest untuk mengetahui kemampuan akhir, dengan rata-rata pada masing-masing kelas yaitu 8,97 dan 11,45. Untuk melihat peningkatan kemampuan komunikasi matematis siswa, dilakukan uji Gain Ternormalisasi pada masing-masing kelas dengan rata-rata 0,53 dan 0,69. Data tersebut kemudian di uji normalitasnya menggunakan uji Lilliefors dengan taraf signifikansi 5\% diperoleh bahwa salah satu kelompok data tidak berdistribusi normal, maka untuk menguji perbedaan peningkatan kemampuan komunikasi matematis siswa menggunakan uji Mann Whitney dan 
diperoleh $Z_{\text {hitung }}=-3,328<z_{\text {tabel }}=-1,96$ berada pada daerah penerimaan $\mathrm{Ha}$. Hal ini menunjukkan bahwa terdapat perbedaan peningkatan kemampuan komunikasi matematis antara siswa yang mendapatkan model Discovery Learning dan Problem Based Learning.

Instrumen yang digunakan untuk mengetahui sikap siswa yaitu menggunakan angket. Angket diberikan kepada siswa sebelum dan sesudah mendapatkan perlakuan dengan model Discovery Learning dan Problem Based Learning untuk meneliti peningkatan Self Confidence siswa terhadap model pembelajaran yang diberikan. Pengolahan data yang digunakan untuk menganalisis sikap tersebut menggunakan skala 10 dengan mengacu pada skala Bandura yang menunjukkan Self Confidence siswa secara umum pada kelas Discovery Learning berinterpretasi baik, dan pada kelas Problem Based Learning berinterpretasi sangat baik.

Sama halnya dengan kemampuan komunikasi matematis, angket awal Self Confidence diberikan sebelum mendapatkan model pembelajaran untuk mengetahui Self Confidence awal setiap siswa. Data dari angket siswa yang telah terkumpul, kemudian diuji normalitasnya yang sebelumnya data tersebut sudah diubah ke dalam bentuk data interval dengan Method of Succesive Interval (MSI). Data yang didapatkan pada angket awal dengan rata-rata pada masingmasing kelas yaitu 43,16 dan 41,65.
Setelah selesai pembelajaran, siswa diberikan angket akhir untuk mengetahui Self Confidence setiap siswa setelah mendapatkan perlakuan dengan rata-rata pada masing-masing kelas yaitu 55,47 dan 57,57. Untuk melihat peningkatan Self Confidence siswa, dilakukan uji Gain Ternormalisasi pada masing-masing kelas dengan rata-rata 0,45 dan 0,64. Data tersebut kemudian diuji normalitasnya menggunakan uji Lilliefors. Karena kedua kelompok data berdistribusi normal dan homogen, maka untuk menguji perbedaan sikap siswa menggunakan Uji-t dengan menggunakan uji dua pihak dengan taraf signifikan 5\% $t_{\text {hitung }}=-3,8<t_{\text {tabel }}=2,00$ berada pada daerah penerimaan $\mathrm{Ha}$, sehingga dapat disimpulkan bahwa: Terdapat perbedaan peningkatan Self Confidence antara siswa yang mendapatkan model Discovery Learning dan Problem Based Learning.

Peneliti menemukan kelebihan maupun kekurangan selama proses pembelajaran dengan Discovery Learning. Kelebihan yang ditemukan diantaranya: a) Dengan kemampuan dan pemahaman yang dimiliki, siswa dapat mengikuti pembelajaran; b) Dalam menyelesaikan masalah dalam Lembar Kerja Siswa, siswa dan kelompok mampu bekerja sama dengan aktif. Kekurangan yang ditemukan diantaranya: a) Kondisi kelas gaduh karena siswa belum memahami permasalahan yang diberikan, keadaan ini membuat konsentrasi siswa berkurang; b) Terbatasnya waktu pembelajaran; c) Pada 
sintak Discovery Learning, tidak adanya presentasi siswa sehingga guru merasa kewalahan untuk membimbing siswa dalam masing-masing kelompoknya agar sampai memahami penyelesaian; d) Terdapatnya kelompok yang kurang termotivasi dalam proses pembelajaran.

Selain itu, peneliti juga menemukan kelebihan juga kekurangan pada model Problem Based Learning selama proses pembelajaran. Kelebihannya yaitu: (a) Memberikan pengalaman baru bagi siswa dengan saling bertukar informasi dalam waktu bersamaan; b) Siswa dapat saling berkomunikasi dengan temannya guna memperoleh informasi dari hasil pengerjaan mengenai materi yang dipelajari; c) Dengan bertukar informasi siswa lebih mudah dalam mendapatkan informasi; d) Siswa terlibat aktif dalam menyelesaikan latihan soal dan berbagi informasi. Kekurangan yang ditemukan diantaranya: a) Beberapa siswa hanya memahami soal yang hanya dikerjakan oleh dirinya sendiri; b) Dengan waktu yang singkat, siswa harus selesai dalam mempresentasikan hasil pengerjaanya.

\section{Penutup}

Kesimpulan dari penelitian ini yaitu kualitas peningkatan kemampuan komunikasi matematis siswa yang mendapatkan model Discovery Learning berdasarkan hasil analisis data gain ternormalisasi sebagian besar memperoleh interpretasi sedang, kualitas peningkatan kemampuan komunikasi matematis siswa yang mendapatkan model Problem Based Learning berdasarkan hasil analisis data gain ternormalisasi sebagian besar memperoleh interpretasi tinggi, terdapat perbedaan peningkatan kemampuan komunikasi matematis siswa yang mendapatkan model Discovery Learning dan Problem Based Learning, kualitas peningkatan Self Confidence siswa yang mendapatkan model Discovery Learning berdasarkan hasil analisis data gain ternormalisasi sebagian besar memperoleh interpretasi sedang, kualitas peningkatan Self Confidence siswa yang mendapatkan model Problem Based Learning berdasarkan hasil analisis data gain ternormalisasi memperoleh hasil yang sama antara interpretasi sedang dan tinggi, dan terdapat perbedaan peningkatan Self Confidence siswa yang mendapatkan model Discovery Learning dan Problem Based Learning. Dari hasil penelitian yang telah didapat, bahwa pembelajaran Problem Based Learning bisa direkomendasikan sebagai pembelajaran yang digunakan oleh guru untuk memfasilitasi peningkatkan kemampuan komunikasi matematis dan self confidence siswa. Ini bisa dilakukan dengan modifikasi guru dalam mengemas rangkaian pembelajaran untuk menunjang kesuksesan dalam mencapai tujuan pembelajaran. 
Adapun saran yang ingin disampaikan adalah: (1) Untuk menerapkan model Discovery Learning dan Problem Based Learning dengan baik diperlukan kesiapan guru dalam membimbing siswa dan menyusun LKS sebagai bahan diskusi agar memudahkan siswa untuk mempelajari materi yang sedang diajarkan; (2) Untuk siswa disarankan lebih memperbanyak latihan soal komunikasi dan lebih aktif dalam pembelajaran, sehingga dapat meningkatkan prestasi; (3) Untuk peneliti selanjutnya disarankan menggunakan kedua model pembelajaran tersebut pada kemampuan matematis dan kemampuan afektif lainnya juga ditinjau dari aspek lainnya.

\section{DAFTAR PUstaka}

Afriansyah, E. A. (2013). Penjumlahan Bilangan Desimal Melalui Permainan Roda Desimal. In Prosiding Seminar Nasional Matematika dan Pendidikan Matematika (pp. 233-240).

Andini, A., Mulyani, N., Wijaya, T.T., \& Supriyati, D.N. (2018). Meningkatkan Kemampuan Komunikasi Matematis dan Self Confidence Siswa Menggunakan Pendekatan PBL Berbantuan Geogebra. Pendidikan Matematika, IKIP Siliwangi, 5(1), 8293.

Arends, R. I. (2009). Learning to Teach (9 th ed.). New York, NY: McGraw Hill Companies, Inc.

Asmara, R., \& Afriansyah, E. A. (2018). Perbedaan Peningkatan Kemampuan
Komunikasi Matematis Siswa antara Model Eliciting Activities dan Discovery Learning. Suska Journal of Mathematics Education, 4(2), 78-87. Damayanti, R., \& Afriansyah, E. A. (2018). Perbandingan Kemampuan Representasi Matematis Siswa antara Contextual Teaching and Learning dan Problem Based Learning. JIPM (Jurnal IImiah Pendidikan Matematika), 7(1), 3039.

Dewi, S. V. (2013). Pengaruh Pembelajaran dengan Pendekatan Pemecahan Masalah terhadap Peningkatan Kemampuan Analisis Sintesis Matematis Siswa SMK. Bandung: UPI. Tersedia: http://respository,upi.edu.

Ghufron, N. dkk. (2011). Teori-teori Psikologi. Jogjakarta: Ar-Ruzz Media.

Hadi, S. \& Novaliyosi. (2019). TIMSS Indonesia (Trends In International Mathematics and Sience Study). Prosiding Seminar Nasional \& Call For Papers.

Hannula, M. S., Hanna, M. \& Erkki, P. (2004). Development of Understanding and Self-Confidence in Mathematics; Grades 5-8. Procedings of the 28th Conference of the International group for the Psychology of Mathematics Education, 3, 17-24.

Hendriana, H. \& Soemarmo, U. (2014). Penilaian Pembelajaran Matematika. Bandung: PT Refika Aditama. 
Hudoyo, H. (2005). Pengembangan Kurikulum dan Pembelajaran Matematika. Malang: UM Press.

Izzati, N. (2010). Komunikasi Matematik dan Pendidikan Matematika Realistik. Seminar Nasional Matematika dan Pendidikan Matematika UNY 27 November 2010. FMIPA UNY. [Online]. Kurniasih, I., \& Sani, B. (2014). Sukses Mengimplementasikan Kurikulum 2013. Yogyakarta: Kata Pena.

Noviyana, I. N., Dewi, N. R. \& Rochmad. (2019). Analisis Kemampuan Komunikasi Matematis Siswa Ditinjau dari Self-Confidence. Prosiding Seminar Nasional Matematika.

Ruseffendi, E. T. (2005). Dasar-dasar Penelitian Pendidikan dan Bidang Non-Eksakta Lainnya. Bandung: Tarsito.

Sari, L. K. (2016). Pengaruh Model Pembelajaran Discovery Terhadap Peningkatan Kemampuan

Komunikasi Matematis dan Self Confidence Siswa. Skripsi. Fakultas Keguruan dan Ilmu Pendidikan Universitas Lampung. [Online]. Tersedia: https://digiblib.unila.ac.id. Savin, M., Baden \& Major, C.H. (2004). Foundation of Problem Based Learning. Maidenhead: Open University Press/SRHE.

Sofyan, D., \& Madio, S. S. (2017). Meningkatkan KEmampuan Pemecahan Masalah dan Komunikasi
Matematik melalui Pendekatan Problem Posing dalam Pembelajaran Matematika di SMA.Mosharafa: Jurnal Pendidikan Matematika, 6(1), 93-104.

Suherman, E. dkk. (2003). Common Text Book: Strategi Pembelajaran Matematika Kontemporer. Bandung: JICA FMIPA UPI.

\section{Riwayat Hidup PENULIS}

\section{Ranti Santika Dewi, S.Pd.}

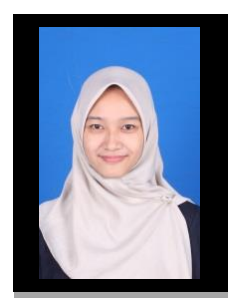

Lahir di Garut, 7 September 1998. Studi S1 Pendidikan Matematika IPI Garut, lulus tahun 2020.

\section{Dr. Rostina Sundayana, M.Pd.}

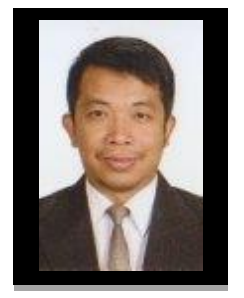
Lahir di Garut, 28 Desember 1966. Dosen PNS DPK di STKIP Garut. Studi S1 Pendidikan Matematika UPI, Bandung, lulus tahun 1996; S2 PKLH Universitas Siliwangi, Tasik, lulus tahun 2009; S2 Pendidikan Matematika UPI, Bandung, lulus tahun 2012; dan S3 Pendidikan Matematika UPI, Bandung, lulus tahun 2018.

\section{Reni Nuraeni, M.Pd.}

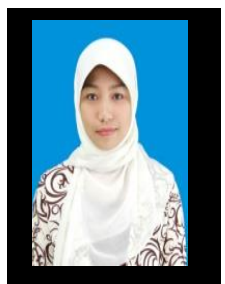

Lahir di Garut, 15 Agustus 1988. Studi S1 Pendidikan Matematika STKIP Garut, lulus tahun 2010; S2 Pendidikan Matematika UPI Bandung, lulus tahun 2014. 